\title{
France's Other Enlightenment: Laïcité, Politics and the Role of Religion in French Law
}

\author{
Herman T. Salton ${ }^{1}$ \\ ${ }^{1}$ Department of International Politics, University of Wales, Aberystwyth, UK \\ Correspondence: Herman T. Salton, Department of International Politics, Room 3.25, University of Wales, \\ Penglais Campus, Aberystwyth SY23 3FE, UK. Tel: 44-197-062-1610. E-mail: hes3@aber.ac.uk
}

Received: August 27, 2012 Accepted: October 22, 2012 Online Published: November 29, 2012

doi:10.5539/jpl.v5n4p30 URL: http://dx.doi.org/10.5539/jpl.v5n4p30

\begin{abstract}
Although the separation of Church and State was a traumatic event for France, this article argues that its legal product - the Law of 1905-was and remains respectful of religious freedom. By considering the relevant literature and by reviewing the key laws and judicial decisions on the matter, this article also suggests that, for France, laïcité represented 'the other Enlightenment', that is to say, a moment when national identity was reawakened, if not formed anew. The piece concludes that the reason for this lies in the fact that, in 1905, France's Founding Fathers had the courage to distance the country's bloody religious past from its legal system, thus producing a statute (the Law of Separation) and a concept (laïcité) that fostered tolerance rather than conflict.
\end{abstract}

Keywords: Laïcité, law of separation of 1905, church and state, Catholic Church, religion, French law, France

\section{Introduction: Laïcité versus Religious Freedom?}

There is a pervasive sentiment in France that la laïcité is central to the country's identity. The French devotion to this peculiar form of secularism-what historian Madeleine Rébérioux has referred to as the French people's "love" for it (Chélini-Pont and Gunn, 2005: 16) - is perhaps understandable given the Nation's turbulent religious history (Note 1). However, the search for a clear definition of the term remains elusive. Despite the impressive number of adjectives which have appeared in scholarly works-including open laïcité (Charlier-Dagras, 2002: 26), closed laïcité (Robert, 2004: 31), strict laïcité (Pena-Ruiz, 2005: 61) and relative laïcité (Airiau, 2005: 17) - there is no commonly accepted explanation of the term. Many pay tribute to the concept, in other words, but none seems to know exactly what it means. This article will argue that the main reason behind this conceptual vagueness lies in the fact that laicite is simultaneously a historical and a legal notion — and that, in this matter, history and law markedly diverge (Note 2).

Historically speaking, the French idea of laïcité has developed in opposition to the Catholic Church and is the product of the events leading up to the unilateral and painful divorce of 1905 (what the French call 'la laïcité de combat', or 'confrontational laïcité). This separation, perhaps inevitably, was marked by a certain degree of hostility towards religion in general and Catholicism in particular. Indeed, even in contemporary France laïcité is considered to have been attained in spite of the Catholic Church. "Separation and laïcité are, historically speaking, very much a secular achievement against Catholic resistance", one author underlined. "They are certainly not a Catholic accomplishment, even though the Catholic Church later came to terms with them" (Poulat, 2003: 119). There is a wealth of historical evidence which supports this assertion. This shift from a theocratic principe de catholicité to a secular principe de laïcité (Poulat, 2003: 120) marks a key moment in French history, and while the transition was long and painful, an overwhelming majority of French people regard it as fundamental to the birth of Modern France (Note 3).

If this historical clash between laïcité and Catholic Church is relatively undisputed, the legal evolution of the concept of laïcité has been far more complex and nuanced. In French law, laïcité is the product of both the 1905 Separation legislation and the rich constitutional framework developed since the 1789 Revolution (in particular, the 1789 Declaration of Human Rights, the 1946 and 1958 Constitutions, and EU and international law). The difficulty arises from the fact that, although laïcité is universally regarded as a key principle of French law, it has never been properly or consistently defined in legal terms (Conseil Constitutionnel, 1977). "Laïcité...awakens passionate and contradictory feelings", one observer explained, "and this results not only in a polarization 
between those in favour and against the idea, but also in a certain confusion over the [legal] meaning of the word and over its implications" (Rivéro, 1949: 137). It is precisely because of this lack of legal accuracy-coupled with the country's tumultuous history - that several commentators interpret French law as the battleground of an epic struggle between secularism and religion, and between laïcité on the one side and religious freedom on the other. The 2004 law regarding religious symbols in schools, for instance, was partly justified on this confrontational basis.

This article adopts a different perspective. It will argue that, from a legal perspective, laïcité and religious freedom are not in competition with each other but complementary to one another. The legal notion of laïcité (as opposed to the historical understanding) is inseparable from - and in fact already contains - the guarantee of religious freedom. Indeed, one cannot exist without the other: a situation of laïcité without religious tolerance would be contradictory as it would betray the spirit of the 1905 law and of French constitutional law. The genius of the Separation's founders, I will argue, lies precisely in their refusal to exclude religion from the rights and freedoms for which the Revolution had so dearly fought.

\section{Religious Freedom in French Law: A Controversial but Crucial Idea}

\subsection{The Protection of Religious Freedom in French Law}

\subsubsection{National Protection}

The commonly held belief that laïcite is the cornerstone of Modern France may be historically sound but is legally inaccurate. Indeed, in terms of the law, the idea of laïcité is chronologically posterior to that of religious freedom: the former was introduced by the education statutes of the 1880s and by the 1905 law on the Separation of Church and State, while the latter dates back to the $18^{\text {th }}$ century (Note 4).

The 1789 Universal Declaration of Human Rights, drafted "in the presence of and under the auspices of the Supreme Being" (Mélin-Soucramanier, 2005: 4), ignored the idea of laïcité but recognised freedom of expression and religion. This was conveyed by Article 11- "[t]he free communication of thoughts and opinions is one of mankind's most fundamental rights: every citizen can therefore speak, write and publish freely with the only limits provided for by the law in case of abuses" (Mélin-Soucramanier, 2005: 7) - as well as by Article 10 - "No-one should be disturbed in his or her opinions, including religious beliefs, as long as their manifestation does not disrupt public order" (Mélin-Soucramanier, 2005: 7). While these provisions were not without controversy, they were avant-garde in extending the protection of the law to religious beliefs as well as to political, philosophical and other opinions, and in granting religious freedom at a time when this was in very short supply (Note 5). The liberal approach of the Déclaration is further confirmed by the fact that one of the proposed drafts of Article 10- "Any citizen who does not trouble the established [Catholic] Church should not be disturbed" - was openly rejected as a violation of religious liberty and was not taken up again in the drafting process (Celerier, 1991: 16).

The recognition of religious liberty in the 1789 Declaration is also apparent in the majority of post-Revolution charters. The 1791 Constitution, for example, granted "the freedom for every man...to exercise the religion to which he belongs" (Messner, Prélot, Woehrling and Riassetto, 2003: 385), while the 1793 text emphasized that "the free exercise of religion" (Constitution, 1793: Art.7) could not be prohibited. Furthermore, the Constitution of 1795 asserted that "No-one can be prevented from exercising, within the limits of the law, the religion of his choice" (Constitution, 1795: Art.354) and the 1814 Constitutional Charter confirmed the freedom of religion while at the same time relying on "the Divine providence" (Constitution, 1817: Art.5/6) and acknowledging the Catholic Church as the official religion. Finally, the 1848 Constitution, drafted "in the presence of God and in the name of the French people" (Messner, Prélot, Woehrling and Riassetto, 2003: 389), acknowledged that "[e]veryone can freely exercise his religion and receive from the State, for such an exercise, equal protection" (Constitution, 1848: Art.7). While it is true that only the 1789 Declaration remains a part of French law, the above-mentioned historical provisions are significant in that they demonstrate how religious freedom has been central to the post-revolutionary constitutional framers. Although the Catholic Church was still the official religion of France, centuries of religious wars and the combined and long-lasting effects of the Enlightenment and the Revolution had made religious freedom a necessity, not a luxury. It is this necessity that laid the groundwork for the eventual separation of Church and State.

This long union was unilaterally broken by the State in 1905, and there is no doubt that the Separation proved to be both acrimonious and rancorous. Yet it is interesting to note that the 1905 statute, commonly regarded as the 'Bible' of French secularism, actually begins with a message of religious tolerance: "The Republic guarantees freedom of conscience. She guarantees the free exercise of religions with the only exceptions being in the interest of public order" (Bruley, 2004: 435). In other words, the public powers must prevent and fight any 
violation of religious freedom. This fundamental principle produced an equally important effect: by ensuring freedom of conscience and by granting the free exercise of religion to all faiths, the State protects the right of every religion to organize its own activities, a marked departure from the 'Gallican' tendencies of previous centuries. In this way, the State also implicitly acknowledges the existence of a domain which is protected from public intervention, except in cases where there is a threat to public order.

Importantly, the 1905 text was later confirmed by the 1946 Constitution, according to which "[e]very human being, without distinction of race, religion or belief, possesses inalienable and sacred rights" (Messner, Prélot, Woehrling and Riassetto, 2003: 387). The statute was finally validated by the 1958 Constitution, in which the first article emphasizes that "[France] ensures equality before the law for all citizens, without distinction on the basis of origin, race or religion. She respects all faiths" (Mélin-Soucramanier, 2005: 28).

\subsubsection{International Protection}

In addition to these domestic provisions, a number of international documents ratified by France similarly guarantee freedom of belief, the most important of which are the International Covenant for Civil and Political Rights (ICCPR), the International Convention for the Protection of the Rights of the Child (ICPRC), the Declaration on the Elimination of Religious Discrimination (DERD) and the European Convention for Human Rights (ECHR) (Note 6). The last of these is particularly important; not only does the French Constitution afford international treaties "an authority which is superior to that of ordinary statutes" (Mélin-Soucramanier, 2005: 23), but European law is also an integral part of French constitutional law. "Everyone has the right to freedom of thought, conscience and religion", Article 1(1) ECHR reads. "This right includes freedom to change his religion or belief and freedom, either alone or in community with others and in public or private, to manifest his religion or belief, in worship, teaching, practice and observance"(Gandhi, 2000: 42).

\subsubsection{Judicial Protection}

The judicial application of these national and international provisions in France has confimed the essential place of freedom of conscience and religion within the French legal system. In 1977, the Conseil Constitutionnel openly acknowledged that "[f]reedom of conscience must be recognized as one of the fundamental principles accepted by the laws of the Republic" (Conseil Constitutionnel, 1977: 42). As for the 1905 statute, it has consistently been interpreted as burdening the French State with a condition of neutrality that is not only negative (all religious beliefs are admitted yet no religion is officially recognised), but also positive (public authorities must intervene to guarantee religious freedom). This implies, for the State, an obligation to ensure that everyone can freely practise his or her religion in day to day life - the duty, as Professor Jacques Robert observed, to "put at the disposal of citizens, if necessary, the public means that allow them to fulfil their religious tenets" (Robert, 1994: 633).

As shall be discussed in further detail below, a series of provisions derive from this obligation, including spiritual assistance for detainees in prisons and other institutions managed by the State ('aumoniers'), recognizance of conscientious objection for military personnel, regulations on the religious slaughtering of animals, supply of halal and other religious food in school canteens, etc. The State must actively implement these provisions. Indeed, Articles 31 and 32 of the 1905 law should be read in this light: despite the system of separation, it is the task of the State to defend the religious practices of its citizens, and one way of doing so is to bring the criminal law to bear against those who commit acts of religious discrimination or who prevent the free exercise of religion (Note 7).

The importance of the French constitutional and statutory provisions on religious freedom is also apparent in the language adopted during the separation process. Article 1 of the 1905 law obliges the State to "ensure" ('assure') and "guarantee" ('garantit') freedom of conscience and belief, introducing a positive form of protection that "does not exclude a certain interventionism from the State" (Charlier-Dagras, 2002: 112). While this may seem logical and to some extent even redundant, in the context of other religious freedom instruments such as the US First Amendment, it is by no means insignificant for a statute that ended fifteen centuries of exceptionally violent religious conflict.

\subsection{The Main Limit to Religious Freedom in French Law: Public Order}

\subsubsection{Public Order in French Law}

Like most civil liberties, religious freedom is not entirely unrestricted in French law, and this section raises the question of whether public order can be regarded as a constraint upon religious freedom. The 1789 Declaration of Human Rights, for instance, protects the expression of religious beliefs "as long as their manifestation does not disturb the public order" (Mélin-Soucramanier, 2005: 7). This is echoed in the 1905 Separation law, which 
guarantees the free exercise of religion "with the only exceptions provided for in the interest of public order" (Bruley, 2004: 435). Indeed, it is "the general spirit of French law", one author observed, "that [religious] freedom must be understood...in the context of the respect of public order" (Charlier-Dagras, 2002: 115).

European and international law are congruent in this respect. In Article 9, the European Convention for Human Rights cites "public safety", "health", "morals" and "other peoples' rights" as the only possible limits to the freedom of expression, most of which fit easily into the broader rubric of "public order". Similarly, the Universal Declaration of Human Rights (1948) refers to "the rights and freedoms of others" (Article 29, Para 2) and to "the just requirements of morality, public order and general welfare in a democratic society" (Article 29, Para 2). Similarly, the International Covenant for Civil and Political Rights provides limitations "as prescribed by law and necessary to protect public safety, order, health, morals or the fundamental rights and freedoms of others" (Gandhi, 2000: 42). Both the International Convention for the Protection of the Rights of the Child (in Article 12) and the Declaration on the Elimination of Religious Discrimination (in Articles 2 and 4) have similar provisions.

\subsubsection{Public Order in the Conseil d'État Jurisprudence}

Importantly, this has also been the consistent position of the Conseil d'État, France's highest administrative jurisdiction. Indeed, since 1905, the Conseil has applied the public order limit sparingly-always as the last resort and always as an exception to the general rule of religious freedom. For instance, all prohibitions of religious manifestations (processions, meetings, ceremonies) not justified by concerns for public order have been upheld as illegal by the Conseil d'État, especially if such events conformed to local traditions (Note 8). Similarly, religious processions have been prohibited only when the risk of disturbance to public order was so serious that the Mayor could not maintain the peace through the deployment of available police forces (Conseil d'État, 1928, 1934 and 1947). If the danger to safety was minor, even non-traditional religious ceremonies have usually been permitted (Conseil d'État, 1948).

The same public order limitations apply to another aspect of French law: the discipline of church bells. Citing religious freedom, the Conseil d'Etat consistently annulled administrative measures that had the effect of limiting or suppressing the sound of church bells unless such limitations were founded on public order (Conseil d'État, 1908, 1910, 1911 and 1923). In this respect, the Conseil seems to have acknowledged and bowed to the liberal spirit of the 1905 legislation from a very early stage. As the statute's rapporteur, Aristide Briand, emphasized during the parliamentary debates, "[e]very time that the public order limit cannot be legitimately invoked, it is the liberal interpretation that will be most respectful of the wishes of the [1905] legislature" (Charlier-Dagras, 2002: 187).

While this case law on religious demonstrations and church bells may appear outdated in $21^{\text {st }}$ century France, the importance attributed to public order as the main limit to religious freedom is by no means a remnant of a bygone age, but is very much a living law. In 1982, for example, the Conseil annulled a préfet's decision to prohibit access to places of religious worship for some members of the Krishna cult, on the grounds that civil servants "have no authority to prohibit a religious ceremony in a given building...except for exceptional reasons of danger to the public order" (Conseil d'État, 1982). Indeed, even in relation to the highly sensitive issue of Islam and the wearing of the Muslim veil at school, the Conseil d'État has, at least until the passage of Statute 228 of 2004, insisted that the headscarf can only be legitimately forbidden if it becomes an issue of public order (Conseil d'État, 2004: 276). Finally, it is precisely such a liberal position that led the judges sitting at Palais Royal to regard certain religious practices_-such as the ritual slaughter of animals (Garay et al, 2005), circumcision (Conseil d'État, 1997), parental rights to their child's religious education (Lazlo-Fenouillet, 1996), absence from school for religious reasons (Conseil d'État, 1995) and the broadcasting of religious programmes on national public networks (Journaux Officiels, 1986) — as in accordance with laïcité.

Public order aside, there is nevertheless another issue that is regularly invoked as a justification for restrictions upon religious freedom in France-and this is the notion of laïcité.

\section{Laïcité in French Law: A Principle of Tolerance, Not Conflict}

Historically speaking, the French idea of lä̈cité has its origins in the education system and was intimately connected with what came to be known as the war of 'the two Frances'. This refers to the two prominent but opposing approaches to schooling in the country, the first of which advocated for the maintenance of the status quo (i.e. Catholic education) while the second supported secular teaching (Baubérot, 2001: 2). It is important to remember that at this time French public education was exclusively Catholic and that until the $19^{\text {th }}$ century the Education Minister was also the Minister of Religious Affairs and a bishop (Cholvy and Chaline, 1995). 
This centuries-long hegemony of Catholic education came to an end in 1882 when, after the victory of the new centre-left coalition, the first of the grandes lois laïques established that "in primary schools, the religious teaching is given outside school buildings and programmes" (Conseil d'État, 1989: 1). In the same year, another piece of legislation emphasized that "in public schools of all levels, the teaching activities are exclusively assigned to non-religious ['lä̈que'] personnel" (Conseil d'État, 1989: 1). Although the word 'lä̈que' was not clearly defined, this truly was a revolutionary moment - and an irreversible one. The transition was subsequently completed through a series of legislative measures including the substitution of "moral and religious instruction" in primary schools for "moral and civic instruction" (Hafiz and Devers, 2005: 17), the abolition of religious distinctions in public cemeteries, the re-establishment of divorce, the abolition of public prayers in Parliament, the prohibition of the crucifix in public schools and the establishment of a State monopoly over funeral services.

Although the Education Laws of the late $19^{\text {th }}$ century were accompanied by strong anti-Catholic sentiments, it should be noted that the philosophy behind them was not anti-religious: "We are not the enemies of religion", Léon Gambetta said in a speech in 1878. "On the contrary, we are the servants of freedom of conscience and we are respectful of all religious and philosophical opinions" (Scot, 2005: 95). The same message was conveyed two years later by Jules Ferry, the architect of the Education Laws, when he declared in Parliament that laïcité by no means equates with aversion towards religion but rather with "the doctrine of freedom of conscience and the independence of...civil society from the religious one" (Scot, 2005: 97). In other words, these politicians sought to efface the historical influence of the Catholic Church over French institutions, not to eradicate religious feelings in general.

\subsection{Tolerant Spirit of the Law of Separation of 1905}

The legislative history and parliamentary debates of the 1905 Statute confirm this position, and they umistakably demonstrate that the Law of Separation was by no means intended to be an act of hostility towards religion. As the rapporteur général and main architect of the law, Aristide Briand, told the French Parliament during the discussion (Bruley, 2004: 331):

I remain more convinced than ever that the Separation must be done in a spirit of marked liberalism. On this point, dear colleagues, I want to insist again ... You are taking back your freedom, so it is only fair that you should leave to the Church her own freedom and that you should let her enjoy it within the limits of public order. This, dear colleagues, is the Separation.

Once the law was passed, Mr Briand congratulated MPs and reiterated the spirit of the legislation: "The Separation [should] not be the product of inter-religious fights [for] the law must be respectful of all faiths and must leave to them the possibility to freely express themselves" (Bruley, 2004: 343).

It is certainly true that a number of parliamentarians, particularly at the extreme left of the political spectrum, voted for the Separation because of their hostility to religion in general and to Catholicism in particular. Yet this does not appear to have been the case for the French Parliament as a whole. The government of Emile Combes, for example, had initially submitted a far more radical draft that established the Separation principle as the sole priority, and that had no clear reminder that religious freedom was to be equally protected (Briand, 1905: 254-302). It was an "anti-clerical and partisan" text (Charlier-Dagras, 2002: 91) that the parliamentary commission did not hesitate to reject altogether unless substantial changes were introduced. These changes eventually led to the successful bill later introduced by Mr Briand.

There are other indications of the liberal character of the 1905 law. The Minister of Education, Jean-Baptiste Bienvenu-Martin, explicitly defended the idea of Separation on the basis that laïcité was the best way of granting citizens a more developed and comprehensive religious freedom. "The statute we are discussing here", he said, "abrogates this kind of unwritten [anti-religious] stance [of the French State] and, in proclaiming the principle of freedom of conscience, it simultaneously establishes its necessary component, i.e. freedom of religion" (Débats Parlamentaires, 1905b: 1211). During the parliamentary debates, the Minister of Religious Affairs similarly stated that it was not his desire to subtract "even the smallest bit of freedom from religions; on the contrary, the Bill introduced to the Senate has the purpose of providing France's various religions with an autonomy that they have never known in the past" (Débats Parlamentaires, 1905c: 1397). Once given the choice between "a Separation accompanied by freedom and another without it" (Débats Parlamentaires, 1905a: 340), the French government as well as the Parliament of 1905 seem to have deliberately chosen the former.

Finally, the conciliatory intention underscoring the 1905 law is suggested by a simple mathematical consideration: the bill would have never been passed with such a comfortable majority (341 votes versus 233) had it not reached out to a number of Catholic MPs and to at least a segment of the Catholic public. "In this country where millions of Catholics practise their religion", the rapporteur emphasized during the debates, "it 
[should be] impossible to even think of a Separation that is unacceptable to them" (Débats Parlamentaires, 1905a: 340). The fact that the Vatican did not immediately accept the partition does not impinge upon the liberal character of the legislation. Indeed, its liberalism is clearly reflected in the provision which favours religious freedom, as well as in a remarkable number of exceptions to the laïcité principle (Note 9). After such a long interpenetration of Church and State, the Separation was certainly difficult for the Catholic Church to accept — historically, psychologically and financially — but the 1905 law was not hostile to religion. Rather, it was hostile to the idea of an established religion, and this, as the First Amendment of the US Constitution shows, is quite a different thing.

As this short overview suggests, laïcité does not imply hostility or even indifference, but rather neutrality towards religion on the part of the State. The exceptions to the Separation principle are so numerous and significant in their favourable attitude toward religious freedom that one cannot help but draw the conclusion that the Separation of Church and State was never meant to be absolute. The concepts of 'Church' and 'State' are, in fact, inseparable and each defines the limits of the other. Understanding them as conflicting ideas is to lose sight of this truth and to grossly underestimate the magnitude of the Separation endeavour.

\subsection{Exceptions to the Laïcité Principle: The Triumph of 'Laïcité Ouverte'}

Given its important and highly sensitive role in French society, it would have been dangerous for the State to ignore religion (Note 10). But the Law of Separation of 1905 did not run that risk. Undoubtedly, the principles established within the legislation include formal non-recognizance and non-financing of religious institutions, yet the exceptions to these principles are so numerous and wideranging that they call into question the extent and significance of the Separation. The following should thus be undertood as examples of how, contrary to what is commonly assumed, the French legal system respects the protection of religious freedom and regards it as a particularly important right, even more important than the venerated laïcité. Indeed, such exceptions demonstrate that more often than not, it is the laïcite that is limited by religious freedom, and not the other way round.

\subsubsection{Religious Services in Prison ('Aumônerie') and Other Public Places}

The first and most obvious exception to the Separation principle is explicitly highlighted in the 1905 law: "All public expenses concerning the exercise of religions will be expunged from the [public] budget", Article 2 reads, except for "those necessary to ensure the free exercise of religion in public buildings such as schools, hospices, kindergartens and prisons" (Bruley, 2004: 435). The State is laïque and therefore must respect the principle of neutrality. However, the assurance of religious freedom provided for in Article 1 (and by French constitutional law in general) requires the State to provide spiritual services to those who cannot freely reach their places of worship (Trotabas, 1960). Thus the principle of laïcité seems to be subordinated to a fundamental freedom that is hierarchically superior to it, and a regime of strict separation between Church and State is, in this instance, impossible to achieve lest freedom of religion be violated (Delavesne, 1905). It should also be noted that it is often the French State that chooses the clerical personnel who oversee spiritual services in public places, illustrating a further exception to the Separation principle. In the army, for instance, clergymen are jointly named by the Defence Minister and the religious institution in question, in schools they are subject to the consent of the principal, and in prisons they are appointed by the Interior Minister and are paid for by the State (Charlier-Dagras, 2002: 126).

\subsubsection{Recognition of Religious Hierarchies}

Article 2 of the 1905 law ensures that "[t]he Republic does not recognize... any religion" (Bruley, 2004: 435), yet as the previous exception concerning the aumônerie suggests, this is largely a legal fiction. The French State has had fruitful and enduring relationships with all the major religions represented in France both before and after 1905. Due to the sovereign status of the Vatican, the relationship with the Catholic Church is the most visible; it follows the rules of international law and both countries have diplomatic missions in each other's territories. Moreover, in the Alsace-Moselle region, the French President still has the right of veto in the nomination of the bishops of Metz and Strasburg (Metz, 1986: 63), though these are usually decided by the Vatican. Similarly, the representatives of Jewish, Muslim and other religions are also regularly consulted by the French State through the Religions Office of the Ministry of Internal Affairs ('Bureau des Cultes'), as well as by the Division for Religious Affairs of the Foreign Office ('Division des Affaires Religieux') (Charlier-Dagras, 2002: 128). Thus, the absence of any official recognition of religion does not prevent the State from engaging in discussions with religious authorities both in France and abroad, as the State-sponsored creation of the Conseil Français du Culte Musulman (CFCM) clearly suggests. In some cases the relationship between State and religious authorities is particularly intriguing: the French President is, for instance, a 'co-prince' of the Andorra Kingdom (where 
Catholicism is still the official religion) together with a Spanish bishop; he is also Chanoine honoraire (honorary clergyman) of the Lateran basilica in Rome (Charlier-Dagras, 2002: 130).

\subsubsection{Financial Exceptions for Religious Activities}

A third important derogation of the Separation principle involves the subsidising of religious activities by the State (Schrameck, 1988). Officially, financing religious activities, organisations or institutions is strictly prohibited, but even in this the French tenet of laïcite demonstrates a curious disconnect between theory and practice (Note 11). The fact that "[t]he Republic...does not finance or subsidize any religion" (Bruley, 2004: 435) does not prevent the French State from giving monetary aid to religious groups or to individuals when this money is meant to support religious activities that are either considered to be of general interest, or that are necessary to ensure the free exercise of religion. Priests are renumerated by the State for providing spiritual counsel (aumôneries) in prisons and schools, for example, or for celebrating the religious funerals of soldiers and statesmen. The Conseil d'État explicitly defined this payment as "a legitimate remuneration for a given service" (Conseil d'État, 1922).

Governmental support of religious buildings provides another clear example of how State financing is acceptable when it is intended to guarantee religious freedom. According to the Law of Separation the French State retains ownership of a large number of Catholic churches but religious associations have the right to use them free of charge (Lamarzelle and Taudiere, 1906: 94). Furthermore, a 1909 statute exempts these buildings-as well as those belonging to religious associations - from property, finance and tax revenue obligations. Other examples of public financing in favour of religion include VAT immunity for all activities of religious associations; indirect public financing for erecting religious edifices that also include a conference room, a museum or a cultural centre; and the maintenance expenses that local governments face to redecorate the religious buildings they own (Charlier-Dagras, 2002: 143). Finally, it should be noted that the generous welfare system of France also assists religious personnel: clergymen and members of religious associations benefit from a number of social security measures (such as illness, pension and maternity leave) which are covered by the State through ad-hoc religious funds (such as the 'Caisse d'Assurance Veillesse des Cultes' and the 'Caisse d'Assurance Maladie des Cultes') (Charlier-Dagras, 2002: 143).

\subsubsection{Religious Freedom in Private and Public Education}

Since laïcité emerged out of the debates concerning religious versus secular education, it is perhaps unsurprising that French people are particularly attached to their education system and perceive it to be the highest expression of the separation between Church and State. While it is certainly true that l'école laïque is a particularly sensitive matter in France, this does not mean that it is hostile to religion. French school canteens, for example, provide a special dietary service approved by Jewish and Muslim authorities. (Charlier-Dagras, 2002: 128). Dietary practices have been recognised as a religious right by the Conseil d'État and the French State supervises them so as to ensure that the sanitary rules regulating the religious slaughtering of animals are both respectful of hygiene and religious tenets (Conseil d'État, 2002: 325). Another exception to laïcité in schools relates to religious holidays: again, France's Conseil has acknowledged that children can excuse themselves from school on the official holy days of their religion and that this is in full accordance with the 1905 law (Conseil d'État, 2002: 325).

It is nervetheless in reference to private education that the religious tolerance of the French legal system is most significant. The right both to impart and to receive a private-and thus also a religious-education has been recognized as having constitutional value in France (Loi des Finances, 1931: 3585). Indeed, a 1959 law explicitly allows the State to support both private and public schools financially, subject to an agreement ('contrat') with the school in question (Chevallier, Grosperrin and Maillet, 1968: 101). While the content of these agreements has been a matter of some controversy, in 1994 the Conseil Constitutionnel openly acknowledged that "the legislator can give financial help to private teaching institutions on the basis of the nature and importance of their contribution to the accomplishment of the teaching mission" (Conseil Constitutionnel, 1994: 832). Without derogating from laïcité, therefore, the French State can and does finance religious instruction, further demonstrating that French law does not favour a system of strict separation but rather one that takes the religious freedom of its citizens into account (Amson, 2004). This position is further illustrated by the tolerance of religious instruction in the classroom: although this cannot be carried out within school programmes, the law dedicates one day a week to optional religious teaching.

\subsubsection{Geographical Exceptions to Separation: Colonial Algeria, Alsace-Moselle and Overseas Territories}

Geographical exceptions to laïcité are arguably the most visible. France never applied the 1905 law to its Algerian colony and the State maintained close relationships with both the Catholic Church and Islam in 
Algerian France. Indeed, it was the French State that paid imams in this region and only those with the prior approval of the French authorities could preach in the mosques (Pierre-Caps, 1990: 1076). Even the organization of the pilgrimage to Mecca was carried out by the French General Governor of Algeria (Haut Conseil à l'Intégration, 2000: 17).

Far from being a feature of the past, these geographical derogations to laïcité are still apparent in contemporary France. The three départements of Alsace-Moselle, for instance, are subject to a different legal status and the 1905 Law of Separation does not apply to them (Regula, 1938). The relationship between Church and State in this Eastern region of France is markedly different from that of the rest of the country, for reasons that are both historical (a product of events that occurred during WWI, Note 12) and sociological (an effect of the distinctive religious attachments of people in this area) (Hafiz and Devers, 2004). So in Alsace-Moselle the French State officially recognises only four religions, namely Catholicism, Protestantism, Judaism and Lutheranism (Conseil d'État, 2004: 266); the school separation between Church and State does not apply and, indeed, public schools provide students with a religious education in the four recognized religions (Leannec, 1997); the French President directly intervenes in - and has a veto power over-the nominations of the Catholic bishops of Strasburg and Metz, as well as those of the other recognized religions (Charlier-Dagras, 2002: 126); and, finally, the prohibition of public financing does not apply and religious ministers from the recognized churches all receive their salary directly from the French State (Charlier-Dagras, 2002: 126). Importantly, in 1925 the Conseil d'État acknowledged the specificity of the legal status of Alsace-Moselle and confirmed that the 1905 Law of Separation does not affect those territories.

It should also be noted that Alsace-Moselle is not an isolated case. Whether the product of historical circumstances or the result of the significant power of the local churches (Conseil d'État, 2004: 269), the 1905 law does not concern a number of French overseas territories (the so-called 'Départements d'Outre-Mer' and 'Territoires d'Outre-Mer') such as the Wallis and Futuna Islands (located in the South Pacific, between Fiji and Samoa), New Caledonia (located in the South-West Pacific) and French Polynesia (located in the Southern Pacific Ocean) (Berre, 1985: 149). The French State retains significant influence over religious affairs in these territories, it continues to co-manage religious activities and to oversee religious communities, and local priests are officially subject to the authority of the representatives of the French State, i.e. the Préfet and the Gouvernateur (Berre, 1985: 149). The Mayotte Island in the Indian Ocean-where the overwhelming majority of the local population is Muslim - provides a particularly interesting example: the 1905 Law of Separation does not affect this territory and instead a special legal status applies that coheres to the particular sociological and demographic circumstances of the island (Conseil d'État, 2004: 271).

These and other geographical exceptions thus serve to indicate that laïcité was never meant to be an immutable dogma, but rather a flexible concept conveying the willingness of the French legal system to respect the habits of the various components of the population. "Laïcité is at its best when it is applied in a tolerant way", one author observed (Goyard, 1984: 344). This system of exemptions sits rather uncomfortably with — and might even be a powerful argument against - the position taken by the French parliament in Statute 228 of 2004 on the matter of religious symbols at school, for it affords considerable leeway precisely to those 'segregationist' tendencies (such as the wearing of a Muslim veil) that French society and politicians so wholeheartedly abhor.

\section{Conclusion: What Place for Religion in French Law?}

The study of laïcité and its application to French law suggests that the historical component of French secularism should not be confused with the legal one.

Historically speaking, there is no doubt that laïcite was the result of a long and painful conflict through which the French State emancipated itself from religion. This historical legacy "has [regrettably] endorsed an ideal and somehow mythic vision of laïcité, which is often considered as a condition of complete indifference towards religious activities. In other words, since the State does not (formally) recognise any religion, some observers have deduced that it should ignore them all. While this is not the state of the law, it is a perception that is still very much present in France's national culture" (Messner, Prélot, Woehrling and Riassetto, 2005: 422). Indeed, this perception partly explains the historical tendency of the French State to control and micro-manage religions.

Yet as this article has argued, the genius of the French separation movement lies precisely in the fact that it had the courage to separate history and law-and to produce a statute that fostered tolerance, not conflict. "One principle is at the heart of the 1905 law: freedom", Dominque de Villepin, a former Prime Minister and an expert on the Separation, wrote. "The law establishes a direct link between laïcité and the revolutionary ideas affirmed in the 1789 Declaration of Human Rights" and, as such, it is "a law of tolerance and peace" (Scot, 2004: 337). The last thing the 1905 legislature intended was to reignite the religious wars of the past centuries. There had 
been too much bloodshed, violence and division: the time had come for tolerance and the only way to ensure such tolerance was to separate the destiny of the French State from that of any religion (Note 13). The Separation Fathers chose freedom over oppression, therefore, and it is in this courageous act that their greatness lies. While the country's violent religious past has certainly left its mark on the legal system, the 1905 statute did not—and could not - encourage an opposition to religion. The Framers realized at a very early stage that doing so would have destroyed individual freedom and would have demolished the very foundations of the separation they were trying to build.

It is precisely for this reason that France's highest administrative court has consistently espoused a tolerant reading of laïcité since 1905. "The Conseil d'État has [adopted] a liberal approach as well as an open conception of laïcite", the institution of Palais Royal wrote in its 2004 Report, which was compiled in the midst of the Muslim veil controversy. "It has always attempted to ensure a liberal application of the Law of Separation by remaining vigilant over the day-to-day implementation of the principle of religious freedom, except for those restrictions required by public order or the organizational rules of the different religions" (Conseil d'État, 2004: 265). In so doing, the high judges arguably embraced Montesquieu, who in his Ésprit des Lois asked whether "it is not the distinctive sign of the genius to know where uniformity is needed and where exceptions are required" (Charlier-Dagras, 2002: 15).

\section{References}

Airiau, P. (2005). Cent Ans de Laïcité Française. Paris: Presses de la Renaissance.

Amson, D. (2004). Les Libertés de l'Ésprit. In Protection des Libertés et Droits Fondamentaux. Paris: Montchrestien.

Baubérot, J. (2001). La Laïcité: Analyses et Réflexions. Paris: Service d'Information du Gouvernement Français.

Baubérot, J. (2004). Laïcité 1905-2005: Entre Passion et Raison. Paris: Éditions du Seuil.

Benvenisti, E. (1999). Margin of Appreciation, Consensus and Universal Standards. New York University Journal of International Law and Politics, 4, 843.

Berre, Y. (1985). Quelques Aspects du Régime Juridique des Cultes dans les DOM/TOM, Supplément, 155, 149.

Briand, A. (1905). Rapport Fait Au Nom de la Commission Relative A La Séparation des Églises et de l'État. Journaux Officiels, Documentation Parlamentaire, Session Extraordinaire, Annexe 2302, 254-302.

Bruley, Y. (2004). La Séparation des Églises et de l'État: Les Textes Fondateurs. Paris: Perrin.

Celerier, T. (1991). Dieu dans la Constitution. Petites Affiches, 67, 16.

Charlier-Dagras, M. D. (2002). La Laïcité Française à l'Epreuve de l'Intégration Européenne. Paris: L'Harmattan.

Chélini-Pont, B., \& Gunn, T. J. (2005). Dieu en France et aux États-Unis. Paris: Berg.

Chevallier, P., Grosperrin, B., \& Maillet, J. (1968). L’Enseignement Français de la Révolution à Nos Jours. Paris: Mouton.

Cholvy, G., \& Chaline, N. J. (1995) .L'Enseignement Catholique en France aux XIXe et XXe Siècles. Paris: Cerf.

Conseil Constitutionnel. (1977). Liberté d'Enseignement et de Conscience: Rec. Cons. Const, 23 November 1977, p.42; GDCC n.26; RJC I, p.52; AJDA 1978, p.565 note J. Rivero.

Conseil Constitutionnel. (1994). Journal Officiel, 15, 832.

Conseil d'État. (1908). Morel, 5 August 1908.

Conseil d'État. (1910). Abbé Carlin, 8 July 1910.

Conseil d'État. (1911). Abbé Savarin, 13 January 1911.

Conseil d'État. (1922). Commune de Perquié, 6 January 1922.

Conseil d'État. (1923). Sieur, Lebrun, Curé d'Harancourt, 12 January 1923.

Conseil d'État. (1928). Abbé Rerolle, 5 May 1928.

Conseil d'État. (1934). Rennus, 31 January 1934.

Conseil d'État. (1947). Cuiller, 2 July 1947.

Conseil d'État. (1948). Jeunesse Indépendante Chrétienne, 5 March 1948. 
Conseil d’État. (1982). Association Internationale Pour la Conscience de Krishna, 14 May 1982.

Conseil d'État. (1995). Consistoire Central des Israelites de France et Autres, 14 April 1995.

Conseil d'État. (1997). Hopital Joseph-Imbert d-Arles, 3 November 1997.

Conseil d'État. (2002). Syndicat National Des Enseignants du Second Degré. Actualité Juridique Droit Administratif (AJDA), 2002, 63 note B. Toulemond.

Conseil d'État. (2004). Rapport Public: Un Siècle de Laïcité. Paris: Documentation Française.

Conseil d'État, Avis n.346.893 du 27 Novembre 1989, Assemblée Générale (Section de l'Intérieur), in Conseil d'État, Jurisprudence du Conseil d'État sur le Port du 'Foulard Islamique' dans les Etablissements Scolaires (Centre de Documentation du Conseil d'État, Paris, 1997, § 1.

Débats Parlementaires. (1905a). Séance du 27 Mars 1905, Journaux Officiels, Chambre des Députés, 28 Mars 1905.

Débats Parlamentaires. (1905b). Séance du 4 Avril 1905, Journaux Officiels, Chambre des Députés, 1211.

Débats Parlamentaires. (1905c). Séance du 18 Novembre 1905, Journaux Officiels, Sénat, 1397.

Delavesne, A. (1905). Du Culte et de Son Exercice Public d'Après la Loi du 9 Décembre 1905 sur la Séparation des Églises et de l'État. Paris: Rousseau.

Evans, C. (2001). Freedom of Religion under the European Convention on Human Rights. Oxford: OUP. http://dx.doi.org/10.1093/acprof:oso/9780199243648.001.0001

Fiala, P. (1991). Les Termes de la Laïcité, in Mots, 27 June.

Gandhi, P. R. (2000). International Human Rights Documents. London: Blackstone.

Garay, A., Chélini-Pont, B., Tawil, E., \& Anseur, Z. (2005). The Permissible Scope of Legal Limitations on the Freedom of Religion or Belief in France, Emory International Law Review, 19, 798.

Goyard, C. (1984). Police des Cultes et Conseil d'État du Concordat à la Séparation. Revue Administrative, 11, 344.

Hafiz, C., \& Devers, G. (2005). Droit et Religion Musulmane. Paris: Dalloz.

Haut Conseil à l'Intégration. (2000). L'Islam dans la République: Rapport. Paris: HCI.

Journaux Officiels. (1986). Lois et Décrets, 1 October 1986, 11760.

Koubi, G. (1991). En Marge d'un Conflit: Observations sur la Liberté d'Opinions, Mêmes, Religieuses. in Petites Affiches, 36, 16.

Lamarzelle, G., \& Taudiere, H. (1906). Commentaire Théorique et Pratique de la Loi du 9 Décembre 1905. Paris: Plon.

Laszlo-Fenouillet, D. (1996). La Conscience. Bibliothèque de Droit Privé, 235, L.G.D.J, 1993, n.254.

Leannec, B. (1977). Cultes et Enseignement en Alsace et en Moselle. Strasbourg: Cerdic.

Loi des Finances. (1931). Journal Officiel, April, 3585.

Mélin-Soucramanien, F. (2005). Constitution de la République Française. Paris: Dalloz.

Messner, F., Prélot, P. H., Woehrling, J. M., \& Riassetto, I. (2003). Traité de Droit Français des Religions. Paris: Litec.

Metz, R. (1986). Le Président de la République Française, Dernier et Unique Chef d'État Au Monde Qui Nomme Encore des Evêques. Revue de Sciences Religieuses, 60, 63.

Nicolet, C. (1982). L'Idée Républicaine en France: Essai d'Histoire Critique. Paris: Gallimard.

Pena-Ruiz, H. (2003). La Laïcité: Textes Choisis. Paris: Flammarion.

Pena-Ruiz, H. (2005). Dieu et Marianne: Philosophie de la Laïcité. Paris: Presses Universitaires de France.

Pierre-Caps, S. (1990). Les 'Nouveaux Cultes’ et Le Droit Public. Revue du Droit Public, 1073 at 1076-7.

Poulat, É. (2003). Notre Laïcité Publique. Paris: Berg.

Regula, J. (1938). Le Droit Applicable en Alsace et en Lorraine. Paris: Dalloz. 
Reutenauer, P. (1906). Nouveau Régime des Cultes en France. Commentaire de la Loi du 9 Décembre 1905 sur la Séparation des Églises et de l'État, des Décrets des 29 Décembre, 19 Janvier et 16 Mars 1906 avec Références aux Circulaires Ministerielles (Administration du Bullettin, Paris, 1906) 35-6.

Rivéro, J. (1949). La Notion Juridique de Laïcité. Recueil Dallos, XXXIII, 137.

Robert, J. (1994). La Liberté Religieuse. Revue Internationale de Droit Comparé, 633. http://dx.doi.org/10.3406/ridc.1994.4893

Robert, J. (2004). La Fin de la Laïcité? Paris: Odile Jacob.

Schrameck, O. (1988). La Fin de la Laïcité Fiscale. Actualité Juridique Droit Administratif, 17, 267-269.

Scot, J. P. (2005). L'État Chez Lui, l'Église Chez Elle: Comprendre la Loi de 1905. Paris: Éditions du Seuil.

Trotabas, J. B. (1960). La Notion de Laïcité dans le Droit de l'Église Catholique et de l'État. Paris: LGDJ, Paris.

\section{Notes}

Note 1. See on this point Nicolet (1982: 114) and Baubérot (2004: 163). This article is a revised version of my Veiled Threats? Islam, Headscarves and Religious Freedom in America and France (2008). All translations are mine.

Note 2. The only certainty about laïcité seems to be its etymology. The word derives from the Ancient Greek 'laikos' which originally meant people. However, the term soon came to refer to a layman, as opposed to someone who taught religion and administered religious practices. The latter was referred to as 'clerikos'. See Fiala (1991: 48-50).

Note 3. As late as 1925, twenty years after the Separation of Church and State, the Catholic hierarchy was writing that "the laïcité laws are wrong [because] they are contrary to God, stem from atheism and replace the real God with the false gods of freedom, solidarity, humanity and science... We cannot obey [them] and we have the right and duty to fight them" (Pena-Ruiz, 2003: 181).

Note 4. According to some authors, French law distinguishes between freedom of conscience ('liberté de conscience') and freedom of religion ('liberté des cultes'). It has been suggested that the former consists of "the right for every individual to adopt the religious belief that he or she chooses", while la liberté des cultes "consists of the right for a person to enact his or her religious practices and external acts" (Reutenauer, 1906: 35-6).

Note 5. The question could be raised, for instance, as to whether the expression "including religious beliefs" ('même religieuses') is a diminutive to be interpreted as "even though religious" or rather a repetition used to reinforce the article's egalitarian significance, like in "including the religious ones" (Koubi, 1991: 16).

Note 6. For the ICCPR, see Articles 2 and 6; for the ICPRC, see Article 12; for the DERD, see Article 2 and 4; for the ECHR, see Articles 9 and 14.

Note 7. Article 31 of the 1905 law reads: "Those who, through acts of violence or threat, oblige a person to exercise or not to exercise a given religion, to be part or not to be part of a religious association, to contribute or not to contribute to the finances of a religion, by threatening him or her with a loss of employment or by exposing him or her to damage to his or her person, family or goods, will be punished with a $5^{\text {th }}$ class criminal sanction". Article 32 reads: "Those who prevent, delay or interrupt the exercise of a religion in the form of troubles or disorders in the premises dedicated to such exercise will be punished in the same way [as per article 31]" (Bruley, 2004: 446).

Note 8. The case law on the matter is extensive. See for example Conseil d'État, Abbé Chalmaudron, 27 January 1911; Conseil d'État, Abbé Plisson, 22 November 1912; Conseil d’État, Abbé Didier, 1st May 1914; Conseil d'État, Rochette et Autres, 16 June 1926; Conseil d'État, Claverie, 17 November 1926; Conseil d'État, Abbé Richob, 23 November 1932; Conseil d'État, Abbé Châtel, 12 December 1934. As for events which conform to local traditions, in 1933 the highest administrative court annulled the decision of a Mayor who had prohibited a series of local religious ceremonies on the grounds that "no reason founded on public order could be invoked in support of this decision" (Conseil d'État, Abbé Cretin, 10 June 1931). A virtually identical mayoral ordinance was also annulled by the Conseil d'État in 1933, again for the absence of a threat to public order (Conseil d'État, Abbé Coiffier, 25 January 1933). Palais Royal upheld a decision prohibiting a public demonstration on the grounds that this event "was of such a nature as to threaten public order" (Conseil d'État, Sieur Guiller, 2 July 1947). See also Conseil d'État, Abbé Desmarest, 22 December 1928; Conseil d'État, Abbé Vroman, 26 July 1932 
Note 9. The Catholic journal La Croix defined Separation Day as "an abysmal day, one of the most painful and humiliating of our times, and one that marks the beginning of a troubling era for France" (Bruley, 2004: 346).

Note 10. The issue of laïcité is extensively debated in contemporary France. In this article I take the unconventional - but by no means unprecedented - step of approaching it from the system of exceptions that the 1905 law introduces, rather than from the dogma it is supposed to embody. To put it in another way, I regard the 'derogations' to the laïcité principle as conveying the essence of the 1905 statute on the Separation of Church and State. As it has been observed, "[i]n many respects it is possible to say that it is the exceptions to the separation regime that allow us to approach, a contrario, a definition [of laïcité]" (Messner, Prélot, Woehrling and Riassetto, 2003: 393).

Note 11. Indeed, it can be argued that the principle established by Article 2 of the 1905 law (prohibition of subventions to religions) is purely theoretical, and that this is necessarily so; French local authorities cannot ignore religious affairs because they still own numerous Catholic places of worship.

Note 12 . These territories were conquered by Germany in 1871 and were returned to France only after WWI (Basdevant-Gaudemet and Messner, 1999: 77-92).

Note 13. If French law had followed the emotional path of the country's religious past, the 1905 statute would have provided not a separation between Church and State and a limitation of religious freedom, but rather a prohibition of religion tout court. Yet this was not the choice of the French framers. Their choice was to make freedom of conscience and religion (which they saw as a socio-cultural necessity) prevail in a context of significant hostility towards religion (which they interpreted as a contingent historical situation, destined to fade away). 